\title{
Analisis Peningkatan Kualitas Parakuat Menggunakan Metode DMAIC Di PT Sogo Logo Indonesia
}

\author{
Parakuat Quality Improvement Analysis Using the DMAIC Method \\ At PT Sogo Logo Indonesia \\ ${ }^{1}$ Diah Septiyana, ${ }^{2}$ Wilda Widyastuti \\ ${ }^{1,2)}$ Universitas Muhammadiyah Tangerang, JL. Perintis Kemerdekaan I no.33 Cikokol Tangerang \\ e-mail: Dee.septie@gmail.com
}

Receive: 16 April $2020 \quad$ Accepted: 09 Februari 2021

\begin{abstract}
PT Solo Logo Indonesia Indonesia is a company engaged in the production of Herbicides, with products namely Parakuat and Glyphosate with various variations. Currently, the quality of Parakuat products at PT Solo Logo Indonesia is not optimal. Products with specifications outside the quality standards specified by PT. Solo Logo Indonesia and is categorized as a defective product. To find out the causes of defects and recommendations to improve quality so that you can see the performance using the DMAIC method as well as to find out the sigma value of the product. The DMAIC method is used to see defects in PT Solo Logo Indonesia, the results obtained were that PT Solo Logo Indonesia with product quality performance was at an average sigma quality level of 2.76-Sigma. This shows that the company is already at a reasonably good sigma quality level, even though it is still possible to beat the resulting products to be more competitive.
\end{abstract}

Keywords: DMAIC, Quality, Sigma, Quality Control

\begin{abstract}
Abstrak
PT Solo Logo Indonesia Indonesia merupakan sebuah perusahaan yang bergerak di bidang produksi Herbisida, dengan produknya yaitu Parakuat, dan Glyphosate dengan berbagai macam variasi. Saat ini kualitas produk Parakuat di PT Solo Logo Indonesia belum maksimal. Produk-produk dengan spesifikasi di luar standart kualitas yang ditetapkan oleh PT. Solo Logo Indonesia dan dikategorikan sebagai produk cacat (defect). Untuk mengetahui penyebab cacat dan rekomendasi untuk meningkatkan kualitas sehingga dapat mengetahui kinerja dengan menggunkan metode DMAIC juga untuk mengetahu nilai sigma dari produk parakuat tersebut. Metode DMAIC digunakan untuk mengetahui defect di PT Solo Logo Indonesia, hasil yang didapatkan yaitu bahwa PT Solo Logo Indonesia dengan kinerja kualitas produk parakuat berada pada tingkat kualitas sigma rata-rata 2.76Sigma. Hal ini menunjukkan bahwa perusahaan sudah berada pada tingkat kualitas sigma yang cukup baik meski masih memungkinkan untuk diperbaiki supaya produk yang dihasilkan dapat lebih kompetitif.
\end{abstract}

Kata Kunci: DMAIC, Kualitas, Sigma, Quality Control

\section{PENDAHULUAN}

Adanya persaingan antar produk yang semakin ketat dewasa ini menuntut setiap perusahaan memberikan yang terbaik bagi konsumennya. Kualitas merupakan salah satu jaminan yang harus diberikan dan dipenuhi oleh perusahaan kepada pelanggan, termasuk pada kualitas produk. Karena kualitas suatu produk merupakan salah satu kriteria penting yang menjadi pertimbangan pelanggan dalam memilih produk. Oleh karena itu, diperlukan 
perbaikan dan peningkatan kualitas secara terus-menerus dari perusahaan sesuai dengan spesifikasi dan kebutuhan pelanggan.

PT. Solo Logo Indonesia merupakan sebuah perusahaan yang bergerak di bidang produksi Herbisida, dengan produknya yaitu Parakuat, dan Glyphosate dengan berbagai macam variasi. Herbisida ini dibuat dengan menggunakan bahan campuran tertentu dengan proses pencampuran bahan didalam tanki mixing. Produk Herbisida ini diproduksi secara Make to Stock dan juga sesuai dengan permintaan dari konsumen (Make To Order). Proses produksinya menggunakan beberapa macam jenis, dimana proses utamanya terdiri dari 3 macam proses yaitu pencampuran bahan baku didalam tanki mixing dan memasukkan hasil produksi ke dalam mesin filling kedalam botol dan pemberian label (finishing).

Tabel 1 Data Cacat Produk Pada Tahun 2015

\begin{tabular}{|c|c|c|}
\hline Bulan & Produk & $\%$ Defect \\
\hline Januari & Parakuat & $20 \%$ \\
\hline Februari & Parakuat & $20 \%$ \\
\hline Maret & Parakuat & $40 \%$ \\
\hline April & Parakuat & $30 \%$ \\
\hline Mei & Parakuat & $50 \%$ \\
\hline Juni & Parakuat & $30 \%$ \\
\hline Juli & Parakuat & $60 \%$ \\
\hline Agustus & Parakuat & $30 \%$ \\
\hline September & Parakuat & $30 \%$ \\
\hline Oktober & Parakuat & $20 \%$ \\
\hline November & Parakuat & $30 \%$ \\
\hline Desember & Parakuat & $30 \%$ \\
\hline \multicolumn{2}{|c|}{ Jumlah rata-rata } & $33 \%$ \\
\hline
\end{tabular}

Dari tabel 1.1 terlihat masih adanya produk cacat yang dihasilkan pada setiap produksi Parakuat rata-rata sebesar 33\% dalam 1 tahun. Sehingga dibutuhkan penelitian yang lebih mendalam untuk meyimpulkan kegagalan dalam proses produksi tersebut. Saat ini kualitas produk Parakuat di PT Solo Logo Indonesia belum maksimal. Produk-produk dengan spesifikasi di luar standart kualitas yang ditetapkan oleh PT. Solo Logo Indonesia dan dikategorikan sebagai produk cacat (defect) yaitu, viscositas diluar dari pada spesifikasi yang telah ditentukan oleh PT Solo Logo Indonesia. Standart range untuk viscositas produk Parakuat yaiitu antara 300-650 cps, yang diukur dengan alat viskositas yang bermerk BrookField Viscometer.

Berdasarkan uraian diatas maka penelitian difokuskan untuk menentukan solusi atas permasalahan tersebut sehingga peneliti memilih metode DMAIC. pada:

Dalam penelitian ini, permasalahan mengenai waktu kerja akan dititikberatkan

1. Bagaimana kinerja produk parakuat dengan menggunakan metode DMAIC di PT Solo Logo Indonesia?

2. Apakah penyebab terjadinya Defect atau mempengaruhi rendahnya nilai sigma untuk produk Parakuat pada PT. Solo Logo Indonesia?

3. Apakah rekomendasi perbaikan yang akan dilakukan untuk mengurangi cacat dan jumlah produk cacat Produk Parakuat? 


\section{METODE PENELITIAN}

Langkah -langkah pada penelitian ini adalah sebagai berikut:

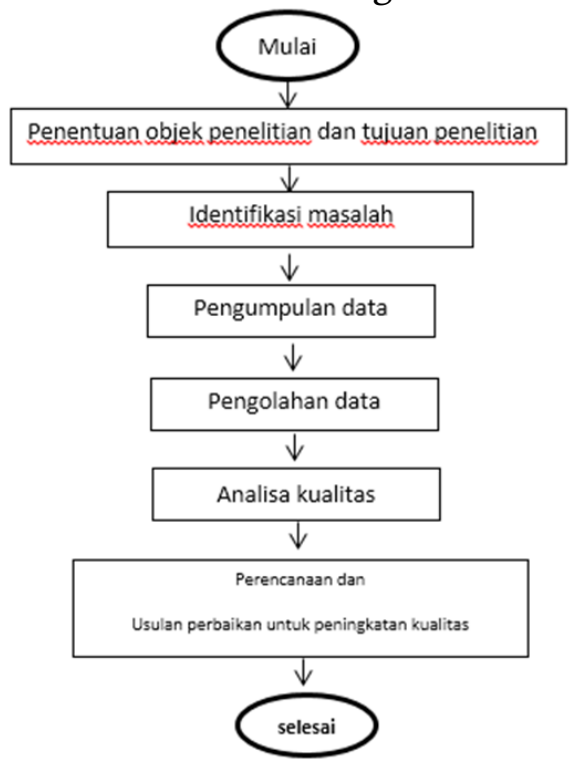

Gambar 1 Flowchart penelitian

\section{HASIL DAN PEMBAHASAN}

\section{A. Tahap Define (Pendefinisian)}

1. Alur proses produksi

Secara singkat dapat dijelaskan bahwa pembuatan parakuat terdiri dari beberapa bahan pokok, bahan kimia, pewarna, dan surfaktan. Untuk lebih jelasnya proses pembuatan parakuat dapat dilihat pada mapping process.

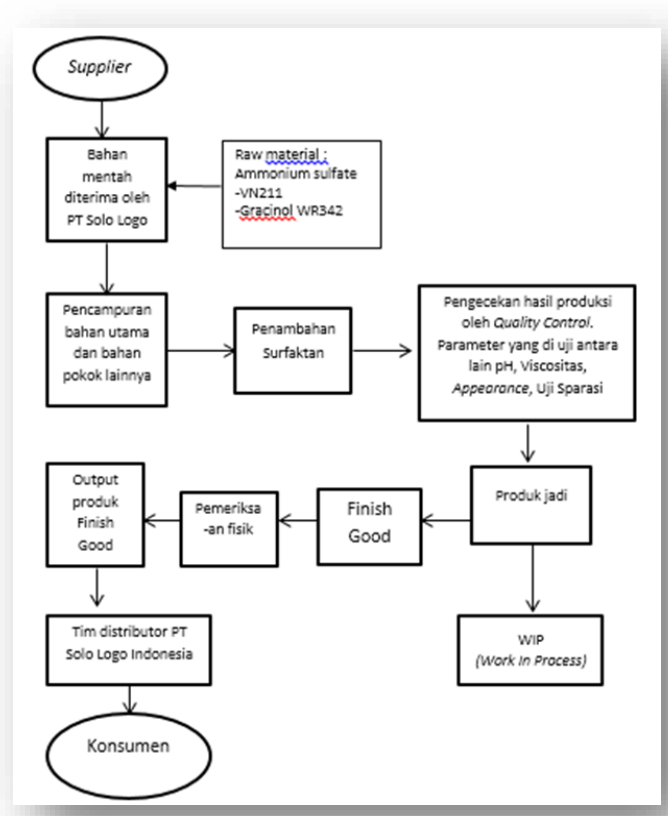

Gambar 2 Flowchart pembuatan produk 
Awal proses pembuatan yaitu pencampuran bahan utama dengan air, hingga menjadi campuran dengan kekentalan yang sudah ditentukan. Selanjutnya pencampuran surfaktan dan warna yang juga dilakukan pada mesin mixing atau pengadukan hingga pencampuran dianggap telah menyatu dengan bahan utama. Pencampuran yang baik atau sesuai akan mendapatkan hasil yang sempurna kemudian dilakukan pengecekan oleh bagian Quality Control.

\section{Penentuan Batas Kendali}

Menentukan batas kendali atas atau Upper Control Limit (UCL) dan batas kendali bawah atau Lower Control Limit (LCL) Karena jumlah bervariasi maka batas kendali dihitung per periode dengan menggunakan diagram $\mathrm{P}$. Pada Diagram $\mathrm{P}$ yang dianalisis adalah persentase atau proporsi dari produk yang cacat (defective) per sampel untuk menilai masingmasing produk dapat diterima atau ditolak.

Unsur-unsur pada diagramnya ditentukan sebagai berikut:

$\mathrm{UCL}=\mathrm{p} \square+3 \frac{\sqrt{\overline{\mathrm{p}}(1-\overline{\mathrm{p}})}}{n}$

Garis tengah:

$\mathrm{CL}=\mathrm{p} \square$

Batas kendali bawah:

$\mathrm{LCL}=\mathrm{p} \square-3 \frac{\sqrt{\overline{\mathrm{p}}(1-\overline{\mathrm{p}})}}{n}$

Dimana:

$\mathrm{p} \square=$ perkiraan proporsi output yang cacai pada populasi

$$
=\frac{\text { jumlah produk cacat }}{\text { jumlah produk yang diobservasi }}
$$

Keterangan :

$\mathrm{p} \square=$ dinyatakan dalam presentasi
$\mathrm{n}=$ jumlah sample

Menghitung perkiraan proporsi output (keluaran) yang cacat pada populasi

$$
\begin{aligned}
\mathrm{p} \square & =\frac{\text { jumlah produk cacat }}{\text { jumlah produk yang diobservasi }} \\
& =\frac{39}{120}=0,325
\end{aligned}
$$

\section{Menghitung UCL, CL dan LCL}

- Batas kendali atas:

$$
\begin{aligned}
\mathrm{UCL} & =\mathrm{p} \square+3 \frac{\sqrt{\overline{\mathrm{p}}(1-\overline{\mathrm{p}})}}{n} \\
& =0,325+3 \times 0.04278 \\
& =0.4534
\end{aligned}
$$

- Garis tengah:

$$
\mathrm{CL}=\mathrm{p} \square \quad=0,325
$$


- Batas kendali bawah:

$$
\begin{aligned}
\text { LCL } & =p \square-3 \frac{\sqrt{\bar{p}(1-\bar{p})}}{n} \\
& =0,325-3 \times 0.04278 \\
& =0.1966
\end{aligned}
$$

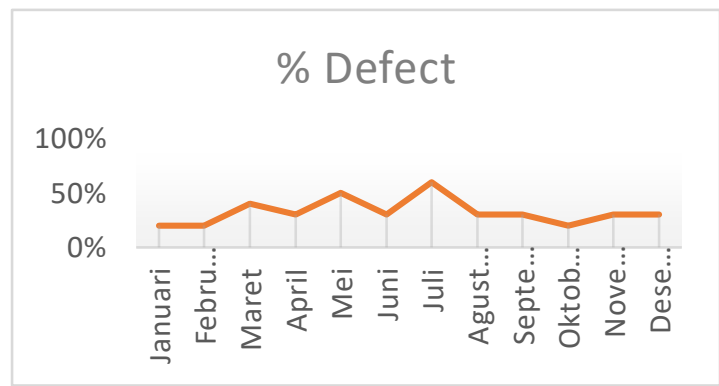

Gambar 3. Line Chart produk Defect

B. Tahap Define (Pendefinisian)

Measure merupakan aktifitas pengukuran proses sebelumnya (pengukuran dasar). Pada tahap kedua ini dilakukan pengukuran terhadap performansi sigma dan memvalidasi permasalahan, mengukur atau menganalisis permasalahan dari data yang ada. Dalam managemen kualitas, pengukuran terhadap fakta-fakta akan menghasilkan data, yang kemudian diolah dan dianalisis. Jika data tersebut diolah dan dianalisis secara tepat, akan memberikan informasi yang akurat, yang selanjutnya informasi tersebut akan berguna bagi manajer untuk mengambil keputusan atau tindakan menejemen untuk meningkatkan kualitas (Gaspersz, 2002).

Fase ini mengukur kinerja pada PT Solo Logo Indonesia sebagai dasar untuk melakukan analisa dan perbaikan dari konsep untuk peningkatan kualitas. Langkahlangkah yang terdapat pada tahap measure ini adalah:

- Menentukan karakteristik kualitas kunci pelanggan (CTQ).

- Mengukur kinerja perusahaan dengan membuat peta control yang dilanjutkan dengan perhitungan DPMO dan level sigma.

Langkah-langkah yang dilakukan untuk pengukuran kinerja proses yaitu:

a. Melakukan perhitungan batas kendali dengan membuat peta kendali berdasarkan data-data proses produksi.

b. Menghitung kapabilitas proses untuk mengetahui apakah saat ini proses produksi sudah cukup capable atau belum.

Langkah-langkah untuk melakukan pengukuran kinerja produk adalah sebagai berikut:

- Menghitung nilai DPU (Defect per Unit) yaitu nilai rata-rata defect per tiap unit untuk mengetahui berapa unit total yang dihasilkan hingga tanpa cacat.

- Menghitung nilai DPO (Defect per Opportunity), DPMO (Defect per Million Opportunity), dan ukuran sigma sesuai dengan DPMO yang dilakukan diperhitungan sebelumnya.

\section{Menentukan karakteristik kualitas kunci pelanggan (CTQ)}

Terdapat beberapa karakteristik kualitas yaitu:

1. Viskositas atau kekentalan 
Yang mempengaruhi kualitas antara lain yaitu pemakaian bahan pengental atau garam pengental, jumlah air, dan jumlah surfaktan yang dipakai.

2. $\mathrm{pH}$

$\mathrm{pH}$ atau derajat keasaman suatu produk berpengaruh pada kelarutan suatu surfaktan terhadap bahan baku utama.

3. SG (Spesific Gravity)

Pengukuran berdasarkan daya grafitas suatu benda. Semakin kenatal produk maka hasil pengukuran grafitasnya semakin rendah.

2. Pengukuran kinerja proses

Pembuatan peta kendali atau $\mathrm{P}$ chart pada produksi parakuat.

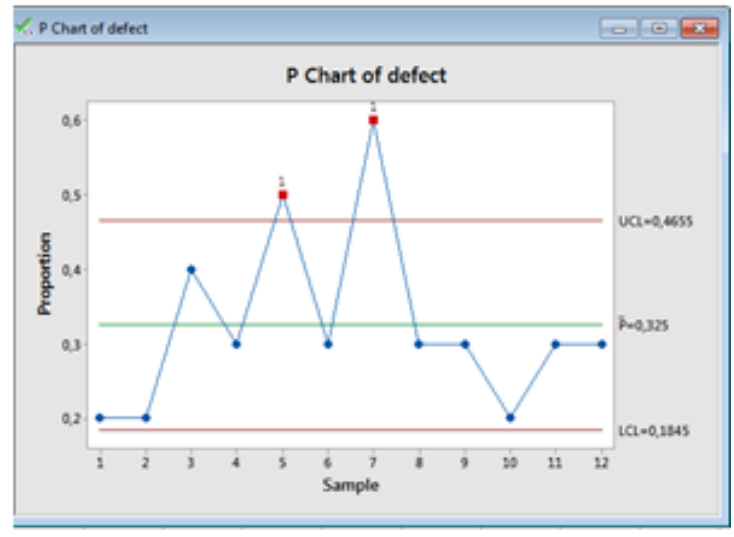

Gambar 4 P Chart of defect software minitab17

Pada peta kendali $\mathrm{P}$ di bawah dapat diketahui bahwa proses produksi produk Parakuat masih belum terkendali dikarenakan terdapat satu sampel yang berada di luar batas pengendali atas yaitu pada bulan ke 5 dan bulan ke 7 .

Tahap Analisis Diagram Kontrol (P-Chart) Data diambil dari PT Solo Logo Indonesia, yaitu pengawasan kualitas yang diukur dari jumlah produk akhir.

Tabel 2 Tabel hasil cacat produk prakuat

\begin{tabular}{|c|c|c|}
\hline Bulan & Defect & $\%$ Akumulasi \\
\hline Januari & 2 & $5.13 \%$ \\
\hline Februari & 2 & $5.13 \%$ \\
\hline Maret & 4 & $10.26 \%$ \\
\hline April & 3 & $7.69 \%$ \\
\hline Mei & 5 & $12.82 \%$ \\
\hline Juni & 3 & $7.69 \%$ \\
\hline Juli & 6 & $15.38 \%$ \\
\hline Agustus & 3 & $7.69 \%$ \\
\hline September & 3 & $7.69 \%$ \\
\hline Oktober & 2 & $5.13 \%$ \\
\hline November & 3 & $7.69 \%$ \\
\hline Desember & 2 & $7.69 \%$ \\
\hline Jumlah & 39 & $100.00 \%$ \\
\hline
\end{tabular}


JT : Jurnal Teknik

P-ISSN: 2302-8734

E-ISSN: 2581-0006

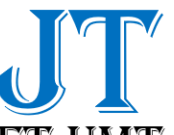

FT UMT
Vol. 10 No. 1 Th. 2021

Halaman : 88 - 97

Januari 2021

\section{Perhitungan Kapabilitas Proses}

Kapabilitas proses ini untuk mengetahui apakah proses produksi pada PT Solo Logo Indonesia telah berjalan dengan abaik atau belum. Sebelum menghitung kapabilitas proses yang ada harus stabil dengan tidak ada titik-titik yang melewati batas statistikal.

4. Perhitungan DPMO (Defect Per Million Opportunities) dan tingkat sigma

Hasil perhitungan DPMO dan nilai sigma dari tiap jenis kecacatan dapat dilihat dari tabel 2 (nilai sigma diperoleh pada lampiran konversi sigma). Adapun langkah-langkah perhitungan DPMO adalah sebagai berikut:

1. Unit (U)

Unit ini merupakan jumlah produk parakuat yang diambil sebagai sample dari bulan Januari sampai Desember 2015 yaitu berjumlah 120.

2. Opportunities (OP)

Opportunities (OP) merupakan karakteristik kualitas yang berpeluang untuk menurunkan kualitas karena terdapat cacat pada produk parakuat berjumlah 3 parameter.

3. $\operatorname{Defect}(\mathrm{D})$

Defect merupakan banyaknya cacat yang timbul dari produk parakuat antara bulan Januari sampai dengan Desember 2015 yaitu sebesar 39 buah.

4. DPU (Defect Per Unit)

$$
\mathrm{DPU}=\frac{\sum \text { cacat }}{\sum \text { produksi }}=\frac{\sum 39}{\sum 120}=0,325
$$

\section{Total Opportunities (TOP)}

$\mathrm{TOP}=\mathrm{U}^{*} \mathrm{OP}=120 * 3=360$

6. DPO (Defect Per Opportunities)

$$
\mathrm{DPO}=\frac{D}{T O P} \quad=\frac{39}{360}=0.1083
$$

\section{DPMO (Deffect Per Million Opportunities)}

$$
\begin{aligned}
\mathrm{DPMO} & =\mathrm{DPO}^{*} 1000,000 \\
& =0.1083^{*} 1000,000=108.300
\end{aligned}
$$

8. Level Sigma

Dari hasil DPMO dapat diperoleh hasil sigma dari hasil konversi atau dengan menggunakan perhitungan manual dengan menggunakan mikrosoft excel. Adapun formula yang digunakan dalam perhitungan program Microsoft Excel sebagai berikut: 
Tabel 3 Tabel perhitungan sigma

\begin{tabular}{|c|c|c|c|c|c|}
\hline Bulan & $\begin{array}{l}\text { Produksi } \\
\text { per bulan }\end{array}$ & Defect & $\begin{array}{c}\text { Banyak } \\
\text { CTQ }\end{array}$ & Dpmo & sigma \\
\hline 1 & 10 & 2 & 3 & 66666,67 & 3 \\
\hline 2 & 10 & 2 & 3 & 66666,67 & 3 \\
\hline 3 & 10 & 4 & 3 & 133333,33 & 2,61 \\
\hline 4 & 10 & 3 & 3 & 100000 & 2,78 \\
\hline 5 & 10 & 5 & 3 & 166666,67 & 2,47 \\
\hline 6 & 10 & 3 & 3 & 100000 & 2,78 \\
\hline 7 & 10 & 6 & 3 & 200000 & 2,34 \\
\hline 8 & 10 & 3 & 3 & 100000 & 2,78 \\
\hline 9 & 10 & 3 & 3 & 100000 & 2,78 \\
\hline 10 & 10 & 2 & 3 & 66666,67 & 3 \\
\hline 11 & 10 & 3 & 3 & 100000 & 2,78 \\
\hline 12 & 10 & 3 & 3 & 100000 & 2,78 \\
\hline \multicolumn{2}{|c|}{ Rata-rata } & 3,25 & 3 & 108333,33 & 2,76 \\
\hline
\end{tabular}

C. Tahap Analyze (Analisis)

Dalam tahap analisis ditujukan untuk mencari akar masalah yang menyebabkan terjadinya cacat. Identifikasi masalah dibantu dengan tool fishbone diagram.



Gambar 5 Diagram sebab akibat

Tabel 4 Tabel Sebab Akibat

\begin{tabular}{|c|c|c|}
\hline Faktor & Sebab & Akibat \\
\hline Material & $\begin{array}{l}\text {-Kelebihan surfaktan } \\
\text {-Tidak ada pengecekan RAW } \\
\text { material } \\
\text {-Kualitas bahan baku yang tidak } \\
\text { stabil }\end{array}$ & $\begin{array}{l}\text { Mempengaruhi } \\
\text { kualitas produk } \\
\text { parakuat }\end{array}$ \\
\hline Man Power & $\begin{array}{l}\text {-Kurang koordinasi } \\
\text {-Tidak focus } \\
\text {-Tidak sesuai prosedur }\end{array}$ & $\begin{array}{l}\text { Kesalahan pada saat } \\
\text { melakukan mixing } \\
\text { parakuat }\end{array}$ \\
\hline Machine & $\begin{array}{l}\text {-Baut sambungan pipa kendur } \\
\text {-Jumlah air yang fluktuatif } \\
\text {-Plastik yang masuk kedalam saringan }\end{array}$ & $\begin{array}{l}\text {-Pompa tidak } \\
\text { kencang } \\
\text { Meteran air tidak } \\
\text { stabil } \\
\text { Saringan tersumbat }\end{array}$ \\
\hline Method & Disesuaikan dengan permintaan consumer & $\begin{array}{l}\text { Prosedur berubah- } \\
\text { ubah }\end{array}$ \\
\hline
\end{tabular}


D. Tahap Improve (Peningkatan)

Tahap perbaikan merupakan tahapan penentuan tindakan-tindakan perbaikan yang ditujukan untuk mengurangi akar masalah. Berdasarkan hasil analisis, usulan perbaikan yang dapat dilakukan perusahaan meliputi:

1. Mencari solusi potensial

Mendokumentasikan semua solusi, analisa statistik atau tools lain yang digunakan untuk mengembangkan solusi, mendaftar semua usulan yang diberikan oleh partisipan proses, pemilik proses.

2. Memilih dan menyusun prioritas terhadap solusi

Memprioritaskan solusi yang telah didaftar dari tahap sebelumnya, kemudian memilih solusi yang harus dilaksanakan terlebih dahulu menurut tingkat kepentingannya.

3. Membuat standarisasi kerja

Peluang perbaikan akan sangat terbatas tanpa adanya suatu standar. Dengan menerapkan banyak standar, maka semakin sedikit pekerjaan yang mengalami kesulitan atau ketidak jelasan prosedur. Bila standar sudah ditetapkan maka operator harus secara konstan menerapkan dan melaksanakan perubahan secara cepat. Standar kerja harus menyangkut tiga elemen pokok, yaitu cycle time, urutan kerja dan jumlah barang yang diproduksi. Standar kerja harus dikembangkan agar dapat diikuti oleh semua operator, biasanya lembar standar kerja dipasang pada setiap pos kerja sehingga memungkinkan semua operator untuk mengikuti instruksi atau prosedur tersebut.

\section{E. Tahap Control (Pengawasan)}

Tahap control merupakan tahap repenting karena perbaikan ulang terhadap proses tidak diinginkan dan keuntungan dari perbaikan terus-menerus yang didapatkan. Pada bagian ini dilakukan rencana pengendalian (control plan) terhadap proses dan memberikan usulan sistem pengawasan manajemen berdasarkan hasil uji coba yang telah dilakukan untuk continuous improvement dan memastikan bahwa setiap pekerja telah dilatih untuk melakukan prosedur perbaikan yang baru. Pada tahap control hanya sampai proses improving sehingga belum dapat dilakukan verifikasi dan implementasi.

\section{SIMPULAN DAN SARAN}

Berdasarkan hasil dan pembahasan maka dapat ditarik kesimpulan sebagai berikut:

1. PT Solo Logo Indonesia dengan kinerja kualitas produk parakuat berada pada tingkat kualitas sigma rata-rata 2.76-Sigma dengan DPMO sebesar 108333,33. Hal ini menunjukkan bahwa perusahaan sudah berada pada tingkat kualitas sigma yang cukup baik meski masih memungkinkan untuk diperbaiki supaya produk yang dihasilkan dapat lebih kompetitif.

2. Penyebab terjadinya cacat pada produk parakuat disebabkan beberapa hal diantaranya:

a. Pada faktor metode, pada faktor ini berdasarkan permintaan pasar yang selalu berubah-ubah dan permintaan khusus dari pelanggan yang mengakibatkan prosedur pengerjaan yang berubah-ubah pula

b. Faktor material, kualitas akan suatu bahan baku juga menjadi sebab penting yang dapat mempengaruhi kualitas viscositas produk yang akan di produksi. 
c. Pada faktor man ini kurangnya koordinasi dengan formulator, sehingga apabila ada perubahan prosedur maka akan mengakibatkan kesalahan informasi yang dapat mempengaruhi kualitas produk, menurunnya daya fokus operator yang diakibatkan dari kelelahan dapat juga mengakibatkan kesalahan pada saat menjalankan prosedur. Pada faktor mesin, hal ini berkaitan dengan volume air pada tanki mixing yang kuantitasnya kurang stabil.

3. Perbaikan yang dilakukan untuk mengurangi banyaknya cacat dan jumlah produk cacat pada produk parakuat adalah sebagai berikut:

a. Mencari solusi potensial

b. Mendokumentasikan semua solusi, analisa statistik atau tools lain yang digunakan untuk mengembangkan solusi, mendaftar semua usulan yang diberikan oleh partisipan proses, pemilik proses.

c. Memilih dan menyusun prioritas terhadap solusi

Memprioritaskan solusi yang telah didaftar dari tahap sebelumnya, kemudian memilih solusi yang harus dilaksanakan terlebih dahulu menurut tingkat kepentingannya.

d. Membuat standarisasi kerja

e. Peluang perbaikan akan sangat terbatas tanpa adanya suatu standar. Dengan menerapkan banyak standar, maka semakin sedikit pekerjaan yang mengalami kesulitan atau ketidak jelasan prosedur

\section{DAFTAR PUSTAKA}

Ariani, D. W. (2004). Pengendalian Kualitas Statistik (Pendekatan Kuantitatif dalam Manajemen Kualitas). Yogyakarta: CV Andi Offset.

Gaspersz, V. (2002). Total Quality Management. Jakarta: PT. Gramedia Pustaka Utama.

Evans, J.R., Lindsay, W.M. (2007). An Introduction to Six Sigma \& Process Improvement (Pengantar Six Sigma), Salemba Empat, Jakarta.

Widiatnolo, S.B. (2010). Analisis Cacat Low Brine dan Low Vaccum Produk Jamur Kemasan Gelas dengan Pendekatan Desain Eksperimen di PT. Zeta Agro Corporation, Skripsi Program Studi Teknik Industri, Universitas Atma Jaya Yogyakarta. 